\title{
THE ABUNDANCE AND MECHANICAL CONTROL OF ICERYA PURCHASI (MASKELL) (HEMIPTERA: MONOPHLEBIDAE) ON MANGIFERA INDICA IN DHAKA, BANGLADESH
}

\author{
Samiha Nowrin, Murshida Begum*, Mousumi Khatun and Moksed Ali Howlader \\ Department of Zoology, University of Dhaka, Dhaka-1000, Bangladesh
}

\begin{abstract}
The cottony cushion scale, Icerya purchasi, one of the devastating pests of citrus and ornamentals distributed all over the world. A study was conducted on the biology, abundance and mechanical control of this pest on mango plants from at two locations of Dhaka, Bangladesh. Simple linear regression lines were produced on the lengths and widths of different nymphal instars and adult of this pest. It was proved that body lengths and widths were highly correlated with the successive changing of the nymphal instars from 1st, 2nd and 3rd to adults. The maximum abundance of the I. purchasi on mango leaves was $310 \pm 21$ in March, 2016. The results of the mechanical control method by hand crushing showed that it was highly effective to control this insect. Abundances of this insect before and after treatment were significantly different $(p<0.05)$. Abundances of insects in different sampling times were showed different by Tukey's HSD test $(p<0.05)$.
\end{abstract}

Key words: Icerya purchasi, Mangifera indica, abundance, mechanical control

\section{INTRODUCTION}

The cottony cushion scale, Icerya purchasi, distributed widely throughout the world and attacks a variety of host plants which has great economic importance (Hale 1970). This is cosmopolitan, abundant in the tropical and subtropical regions in the world. Being euryphagous, their feeding was dependent on a large variety of plants viz., Citrus spp. including lemon, grapefruit and orange, Casuarina sp., Pittosporum sp., Mangifera sp. and Rosa sp. As female adults are hermaphrodites, they can reproduce by self-fertilization (Hughes-Schrader 1930). Like other hemimetabolous insects it has five developmental stages including egg, first instar, second instar, third instar larvae and the adult. Approximately 60 days are required for the pest to reach to adult stage from egg and average life span of a healthy pest is around 100 days (Riley 1889 and Silvestri 1909). Soon after the discovery in the United States, $I$. purchasi became one of the most economically important pests of citrus (Ebeling 1959). I. purchasi found to be a serious threat to plants which is difficult to control even using chemicals (Causton et al. 2004). This insect mainly attacks branches, twigs and leaves of the host plants. The leaves and smaller twigs of

* Author for correspondence: <murshida.begum@du.ac.bd> 
the host plants are primarily damaged by the immature stages of the scale due to their feeding dependency. The host plants experience defoliation, fruit drop and the decrease of vitality with the increase of the level of infection. Older nymphs and adults continue to feed. Older nymphs are mostly seen in larger twigs whereas adults migrate to the larger branches and stems (Hamon and Fasulo 2005). Moreover, plants are further damaged by the sooty molds, grown on the discharge of immature I. purchasi (Grafton-Cardwell 2003). Notably, fruit trees are also affected by an incurable blight due to I. purchasi. Extensive works have been conducted on the infestation effect of cottony cushion scale, I. purchasi, on the growth and yield of different crops (Kim et al. 2011, Rubiales and Fernandez-Aparicio 2009, Watson and Maluphy 2004). Some reports on this fauna are also available in the south East Asian regions. In these regions, remarkable research has been conducted on the Indian scale insect (Kumari et al. 2014). As far known, no research work on the study of control of $I$. purchasi was observed in Bangladesh. However, the research describes the abundance, biology and the mechanical control of this insect in the selected area of Dhaka city, Bangladesh during particular experimental period.

\section{MATERIAL AND METHODS}

The Samples were collected from Ruqayyah Hall, Zoological Garden and Botanical Garden of the area of University of Dhaka. The insect samples were also collected from a park of Sector 13, Uttara, Dhaka, Bangladesh.

Study of abundance and biology: A field observation on the abundance and biology was performed by selecting host plants of above-mentioned areas of Dhaka city during the experimental period. The leaves and twigs of the host plants with different stages of the scales were collected from the experimental plants. During the time of sampling, the ambient temperature and relative humidity (RH) were recorded using a thermo-hygrometer.

Total 36 number of $M$. indica at Dhaka University campus and 44 located in the park of sector number 13, Uttara, Dhaka were observed during the study. In each area, about $10 \%$ of the plants were selected using a random sampling method. A grid of $1 \mathrm{~mm}^{2}$ cells was engraved on a thin plastic sheet which was used for counting the number of cottony cushion scale on the leaves and the peduncles of the host plant. Different life stages of the insects were isolated and identified. The specimens were mounted with glycerin under coverslips and observed under a compound light microscope (Humascope Classic 2006/95/ EC). The length and widths of all life cycle stages of the pest were measured using an ocular and stage micrometer. The photographs were taken using a Nikon $\mathrm{F}_{60}$ camera to record all the life cycle stages. For the study of abundances, 
mean number of the larvae and adults per peduncle and per leaf were recorded during May, 2015 to September, 2015.

Mechanical control: When the population of the pest reached a maximum level on most of the plants, a mechanical control measure was applied. In this practice, the cluster of pests was killed by hand crushing wearing a thin rubber glove. The effects of the control treatment on the reduction of the pests were observed by counting the number of scale insect present on the untreated and treated leaves and peduncles. The control measures were applied at the start of the first week of the particular month and the observation of the scale insect infestation level was recorded on the last week of the same month. Thus, every month starting from October, 2015 mechanical control measures were applied on the selected host plants for the subsequent study of infestation level.

Relative abundances of mechanically treated insects were calculated using the following formula (Abbott 1925):

Abundance of insects on untreated parts - Abundance of insects on treated parts

Abundance of insects on untreated parts $\times 100$

Statistical analyses: Data were presented as mean and standard deviations (SD). Simple linear regression lines were also produced to correlate the size with the life cycle stages of $I$. purchasi. The mean number of the insects in untreated and treated leaves and peduncles were compared by paired $t$ test. The abundance of $I$. purchasi on leaves and peduncles of mango plants during the whole study period were compared by Tukey's HSD (Tukey 1949).

\section{RESULTS AND DISCUSSION}

Biology: The study revealed that the Icerya purchasi had eggs (photo not shown), three nymphal instars and adults during its life time (Fig. 1). The eggs of $I$. purchasi were orange in color, elongate-oval in shape, and smooth in texture. The mean length was $0.71 \pm 0.05 \mathrm{~mm}$ and the mean width, $0.31 \pm 0.02$ $\mathrm{mm}$. It was flattened dorso-ventrally and slightly convex dorsally (Hale 1970). Newly hatched crawler was convex dorsally; the antennae were 6-segmented. Mean body length was $0.68 \pm 0.02 \mathrm{~mm}$ and the mean width was $0.34 \pm 0.03 \mathrm{~mm}$ (Hale 1970). In comparison to the crawlers, the first instar nymphs (sessile) were identical in shape but slightly larger in size and externally covered with a layer of white waxy material (Hale 1970). In the present study, no data are available from eggs and crawlers. Length and width of the different nymphal instars and adults are presented as mean $\pm \mathrm{SD}(\mathrm{mm})$ (Table 1$)$. The mean length of the newly formed first instar nymph was $0.76 \pm 0.05 \mathrm{~mm}$ and the width, $0.41 \pm 0.03 \mathrm{~mm}$. 
The shape and size of the second instar nymph slightly differ from the first instar. The body of second instar nymph was larger, rounder with heavier, thicker legs and antennae in comparison to the first instar nymph. The mean body length and width were $1.42 \pm 0.25$ and $0.82 \pm 0.04 \mathrm{~mm}$, respectively. The third instar nymphs were reddish in color, oval in shape and entire body was
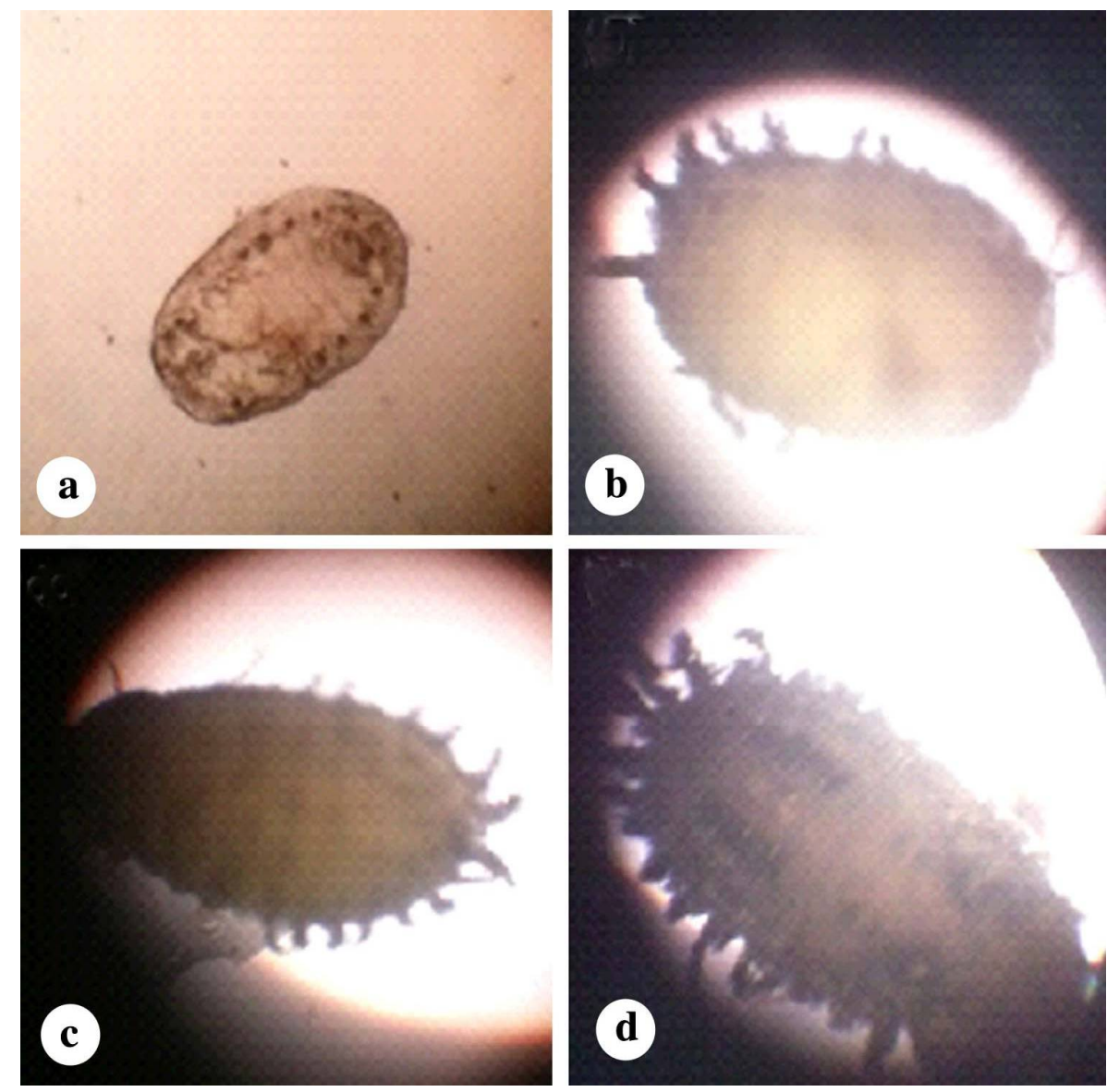

Fig. 1. Microscopic view of the development stages of cottony cushion scale, I. purchasi: (a) First instar nymph. (b) Second instar nymph. (c) Third instar nymph and (d) adult.

covered with waxy-cotton secretion. Mean body length and width were $2.35 \pm$ 0.46 and $1.38 \pm 0.29 \mathrm{~mm}$, respectively. The color of the adults were orange/reddish brown and the entire body was covered with white waxy secretion. The mean body length and width of the newly molted adult were approximately $3.80 \pm 0.35$ and $2.20 \pm 0.21 \mathrm{~mm}$, respectively. In Bangladesh, there is no clear picture about the biology I. purchasi. Results of the present 
research are very nearer to the findings of the Riddick (1955), Hale (1970) and Esfandiari et al. (2007). Simple linear regression lines showed that increasing of the lengths and widths were highly correlated with the successive moulting of the nymphal instars (1st, 2nd and 3rd) to adults (Fig. 2). The results were in agreement with the results found by Hale 1970.

Table 1. Lengths and widths of different nymphal stages and adult $I$. purchasi collected from the experimental mango plant

\begin{tabular}{lcc}
\hline Stages & $\begin{array}{l}\text { Length (in mm) } \\
\overline{\boldsymbol{x}} \pm \text { S.D }\end{array}$ & $\begin{array}{c}\text { Width (in mm) } \\
\overline{\boldsymbol{x}} \pm \text { S.D }\end{array}$ \\
\hline First instar nymph & $0.76 \pm 0.05$ & $0.41 \pm 0.03$ \\
Second instar nymph & $1.42 \pm 0.25$ & $0.82 \pm 0.04$ \\
Third instar nymph & $2.35 \pm 0.46$ & $1.38 \pm 0.29$ \\
Adult & $3.80 \pm 0.35$ & $2.20 \pm 0.21$ \\
\hline
\end{tabular}

*The means were calculated from 10 samples $(n=10)$.

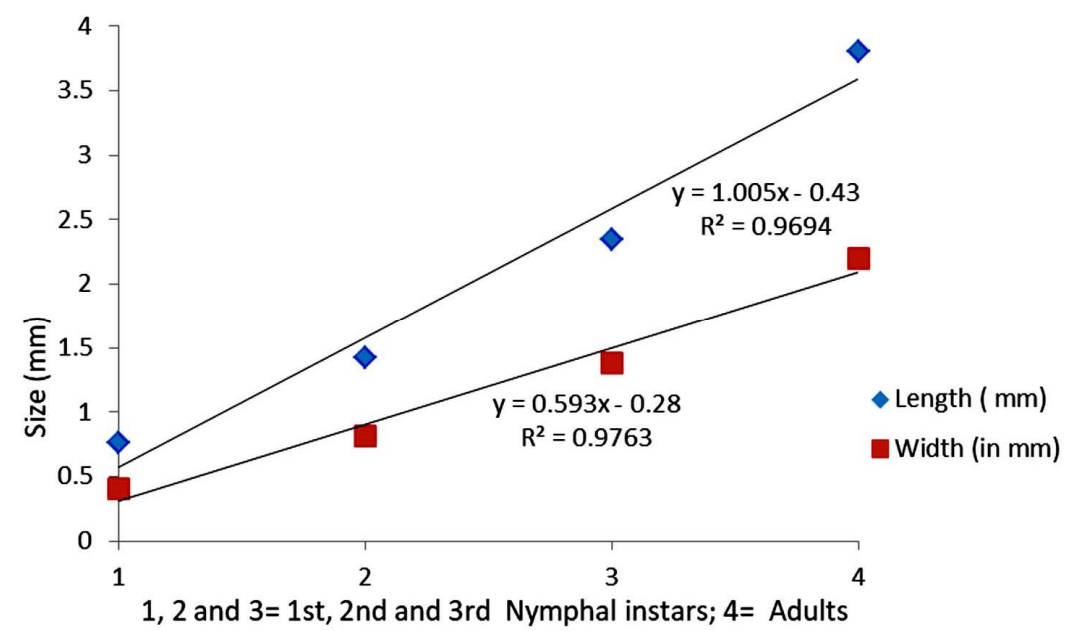

Fig. 2. Simple linear regression lines showing the increase of the length and width of the I. purchasi as the insect was moulted successively from 1st instar nymph to adult.

Abundance and mechanical control: It was observed that the initial infestation began on the soft parts of the host plants such as the young leaves, new stems, and peduncles. Abundance of I. purchasi on peduncles and leaves of untreated mango plants during a period of five sampling days from May, 2015 to September, 2015 are presented in Table 2. The abundance of the pest, $I$. purchasi on different parts of the untreated and the mechanically treated host plants, during a period of six sampling dates from October, 2015 to March, 2016 are presented in Table 3 . The highest abundance of this scale insect $(310 \pm 21)$ 
was present on the leaves of untreated mango plants in March, 2016 (Table 3) and the lowest abundance $(45 \pm 12)$ in the untreated plants observed in May, 2015 (Table 2). Insect abundance of treated and untreated leaves and peduncles were significantly different in the study period $(\mathrm{p}<0.05)$ (Table 3 ). Relative abundance of the mechanically treated insects in the leaves and peduncles during the experimental periods are presented in Fig. 3. The highest $80.65 \%$ of insect could be controlled in the month of March, 2016 on leaves (Fig. 3). Observation of the relative abundance of the insect revealed that there was no big difference in the insect control between leaves and peduncles during the whole experimental period.

Table 2. Abundances of $I$. purchasi on per peduncle and per leaf of mango plants during May, 2015 to September, 2015

\begin{tabular}{lcc}
\hline $\begin{array}{l}\text { No of sampling } \\
\text { days }\end{array}$ & $\begin{array}{c}\text { No. of scale insect on peduncle } \\
\boldsymbol{X} \pm \mathrm{SD}\end{array}$ & $\begin{array}{c}\text { No. of scale insect on leaf } \\
\overline{\boldsymbol{X}} \pm \mathrm{SD}\end{array}$ \\
\hline 1 (May) & $105 \pm 10 \mathrm{~d}$ & $45 \pm 12 \mathrm{~d}$ \\
2 (June) & $80 \pm 8 \mathrm{e}$ & $75 \pm 11 \mathrm{c}$ \\
3 (July) & $117 \pm 20 \mathrm{c}$ & $109 \pm 12 \mathrm{~b}$ \\
4 (August) & $170 \pm 11 \mathrm{~b}$ & $149 \pm 11 \mathrm{a}$ \\
5 (September) & $204 \pm 15 \mathrm{a}$ & $158 \pm 10 \mathrm{a}$ \\
\hline
\end{tabular}

*The means were calculated from 10 samples $(n=10)$. Mean representing the different letters were significantly different $(\mathrm{p}<0.05)$.

Table 3. The abundance of $I$. purchasi on per leaf and per peduncle of the untreated and the treated host plants during October, 2015 to March, 2016

\begin{tabular}{|c|c|c|c|c|}
\hline \multirow[b]{2}{*}{ Months } & \multicolumn{2}{|c|}{ Leaf } & \multicolumn{2}{|c|}{ Peduncle } \\
\hline & $\begin{array}{c}\text { Before treatment } \\
\text { leaf } \\
\overline{\boldsymbol{x}} \pm \mathrm{SD}\end{array}$ & $\begin{array}{c}\text { After treatment } \\
\text { leaf } \\
\overline{\boldsymbol{x}} \pm \mathrm{SD}\end{array}$ & $\begin{array}{c}\text { Before treatment } \\
\text { peduncle } \\
\overline{\boldsymbol{x}} \pm \mathrm{SD}\end{array}$ & $\begin{array}{c}\text { After treatment } \\
\text { peduncle } \\
\boldsymbol{X} \pm \mathrm{SD}\end{array}$ \\
\hline October, 2015 & $150 \pm 10 d$ & $75 \pm 5 a$ & $175 \pm 14 d$ & $73 \pm 5 c$ \\
\hline November, 2015 & $165 \pm 13 d$ & $52 \pm 7 c$ & $155 \pm 14 \mathrm{e}$ & $56 \pm 8 \mathrm{e}$ \\
\hline December, 2015 & $105 \pm 16 \mathrm{e}$ & $60 \pm 10 b$ & $230 \pm 15 b$ & $84 \pm 9 b$ \\
\hline January, 2016 & $210 \pm 13 c$ & $81 \pm 12 a$ & $205 \pm 13 c$ & $96 \pm 16 a$ \\
\hline February, 2016 & $245 \pm 19 b$ & $79 \pm 11 a$ & $150 \pm 17 \mathrm{e}$ & $65 \pm 12 d$ \\
\hline March, 2016 & $310 \pm 21 a$ & $60 \pm 12 b$ & $245 \pm 19 a$ & $92 \pm 11 a$ \\
\hline
\end{tabular}

*The mean of each month contains the data of 10 samples. The means were compared by paired $t$ test. Mean representing the different letters were significantly different $(p<0.05)$. 


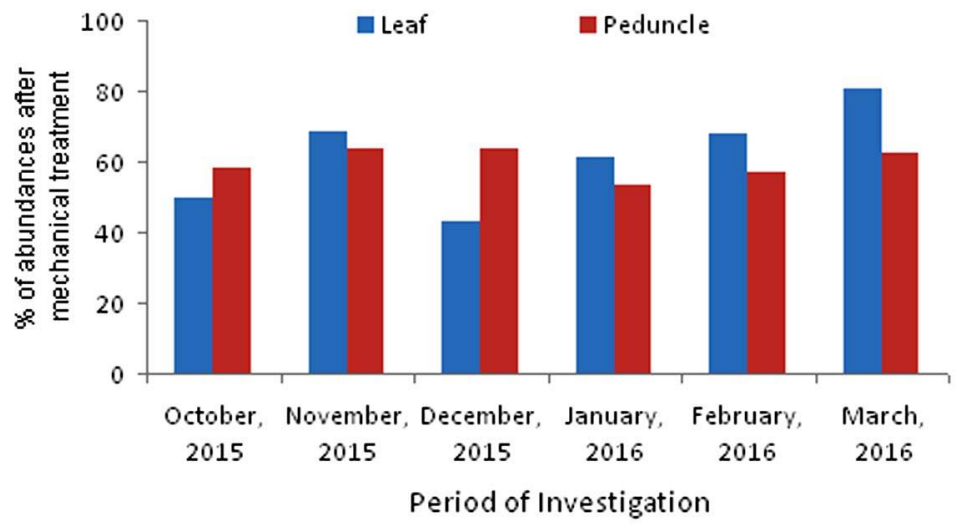

Fig. 3. Comparison of relative abundances of insects on leaves and peduncles of $M$. indica after mechanical treatment of the plants during the experimental periods.

Previous workers showed that the maximum abundance of this pest occurred in the month of March (Aubert 1987, Behura and Bohidar 1983 and Khan et al. 1989). Present researchers also observed similar results (Table 3). Moreover, Jacas and Urbaneja (2010) observed the maximum abundance of this pest was on the leaves which agreed to the present study. Comparing to the previous workers (Causton et al. 2004, Aubert 1987, Behura and Bohidar 1983) the results of the present research demonstrated that the I. purchasi was a serious mango pest. To retain the growth of the host plants and increase of the net production of this fruit, successful control of I. purchasi was necessary.

All the life stages of I. purchasi are covered with wax, which reduces the effectiveness of most chemical insecticides (Miret and Mari 2001). The use of insecticides prevents regulation by natural enemies, which has shown to be highly successful with this species (Miret and Mari 2001) but damage to the populations of biocontrol agent can cause an outbreak of I. purchasi, as recorded in South Africa by Hattingh and Tate (1995). Considering all these aspects, the present researchers have applied the mechanical control method in controlling this insect pest. To retain the growth of the host plants and increase the net production of the fruits, a mechanical control measure was found to be quite successful in reducing the pest number.

\section{LITERATURE CITED}

ABBOTT, W.S. 1925. A method of computing the effectiveness of insecticides. J. Econ. Entomol. 18(2): 267-269.

AUBERT, B. 1987. Trioza erytreae Del Guercio and Diaphorina citri Kuwayama (Homoptera, Psylloidea), the two vectors of citrus greening disease: biological aspects and possible control strategies. Fruits 42: 149-162. 
BEHURA, B. and BOHIDAR, K. 1983. On the haemocytes of four species of aphids. Pranikee 4: $376-379$.

CAUSTON, C.E., LINCANGO, M.P. and POULSOM, T.G. 2004. Feeding range studies of Rodolia cardinalis (Mulsant), a candidate biological control agent of Icerya purchasi Maskell in the Galapagos Islands. Biol. Control. 29: 315-325.

EBELING, W. 1959. Subtropical fruit pests. University of California Berkeley, California, USA. $\mathrm{vl}+436 \mathrm{pp}$.

ESFANDIARI, M., MOSSADEGH, M.S. and ESLAMIZADEH, R. 2007. Biology of the cottony cushion scale, Icerya purchasi Mask. (Hom.: Margarodidae) in laboratory and its seasonal fluctuations in Citrus Orchards of Northern Khuzestan. Water and Soil Sci. 10: 393-403.

GRAFTON-CARDWELL, E.E. (2003). "Cottony cushion scale pest notes." UC ANR Publication. 7410: 3.

HALE, L.D. 1970. Biology of Icerya purchasi and Its natural enemies in Hawaii, Hawaiian Entomol. Soc. 20: 533-550.

HAMON, A.B. and FASULO, T.R. 2005. Featured creatures fact sheet: Icerya purchasi Maskell (Insecta: Hemiptera: Margarodidae). EENY-034. University of Florida. (http://entnemdept.ufl. edu/creatures/fruit/cottony_cushion_scale.htm).

HATTINGH, V and TATE, B. 1995. Effects of field-weathered residues of insect growth regulators on some Coccinellidae (Coleoptera) of economic importance as biocontrol agents. Bulletin of Entomol. Res. 85: 489-493.

HUGHES-SCHRADER, S. 1930. Contributions to the Life History of the Iceryine Coccids, with special reference to parthenogenesis and hermaphroditism. Ann. Entomol. Soc. Am. 23: 359-380.

JACAS, J. A. and URBANEJA, A. 2010. Biological control in citrus in Spain: from classical to conservation biological control. In Integrated management of arthropod pests and insect borne diseases Springer Netherlands. pp. 61-72.

KIM, D.H., YANG, J.Y., JANG, Y.S., SAN CHOI, K., HYUN, H.N. and KIM, D.S. 2011. Stage-specific population dynamics of cottony cushion scale, Icerya purchasi (Hemiptera: Monophlebidae), in citrus orchards in Jeju, Korea. J. Asia Pac. Entomol. 14: 305-309.

KUMARI, D.A., ANITHA, V. and LAKSHMI, B.K.M. 2014. Evaluation of insecticides for the management of scale insect in mango (Mangifera indica). Int. J. Plant Prot. 7: 64-66.

MIRET, J. J. and MARI, F. G. 2001. Side-effects of pesticides on selected natural enemies occurring in citrus in Spain. Pesticides and Beneficial Organisms IOBC/wprs Btlletin. 24: 103-112.

RIDDICK, E.D. 1955. List of Florida plants and the scale-insects which infest them. Bulletin (State Plant Board of Florida); 7.

RILEY, C.V. 1889. Report of the entomologist. Washington: USDA.

RUBIALES, D. and FERNÁNDEZ $\square$ APARICIO, M. 2009. First report of cottony $\square$ cushion scale (Icerya purchasi) on red berried mistletoe (Viscum cruciatum). Entomol. Res. 39: 95-96.

SILVESTRI, F. 1909. A survey of the actual state of agricultural entomology in the United States of America. Hawaiian Forester Agric. 6: 287-336.

TUKEY, J. W. 1949. Comparing individual means in the analysis of variance. Biometrics 5: 99-114.

WATSON, G. W. and MALUMPHY, C. P. 2004. Icerya purchasi Maskell, cottony cushion scale (Hemiptera: Margarodidae), causing damage to ornamental plants growing outdoors in London. Brit. J. Ent. Nat. Hist. 17: 105-109. 